\title{
ZŁA TRADYCJA. DELEGALIZACJA CORRIDY DE TOROS W KATALONII
}

\author{
BAD TRADITION. BULLFIGHT'S PROHIBITION IN CATALONIA
}

\begin{abstract}
This article presents the process of banning bullfighting in Catalonia, which led ultimately to cease its organization in 2012. Discussion about bullfighting in Catalonia is an equally political, social and ethical issue. Outlawing the bullfights is a demonstration of province autonomy against the central government, but is also a manifestation of changes in the social sensitivity towards animals. Decision of the Parliament of Catalonia also activated its local supporters of bullfighting who began a legislative battle which aims to restore bullfights spectacles on Barcelona's arenas.
\end{abstract}

Key words: bullfight; Catalonia; nationalism; tradition; culture; separatism; Spain

Streszczenie

Od stycznia 2012 roku w całej Katalonii zakazane jest organizowanie corridy de toros. Decyzja ta została podjęta przez Autonomiczny Parlament Kataloński w sierpniu 2010 roku. Delegalizacja corridy de toros spotkała się z przychylnym przyjęciem ze strony przeciwników tradycji tauromachicznych (z udziałem byków). Ze strony zwolenników corridy de toros posypały się natomiast formalne oskarżenia o niekonstytucyjność uchwały. Katalonia jako region autonomiczny już od czasów historycznych charakteryzowała się specyficzną kulturą i językiem, co zawsze było fundamentem poczucia odrębności kulturowej i etnicznej Katalończyków wobec innych grup tworzących Hiszpanię. Nie od dziś wiadomo, że Katalonia ma tendencje

MAGDALENA ZIÓtKOWSKA-KUFLIŃSKA Uniwersytet im. Adama Mickiewicza, Poznań

E-mail: hfacb@hotmail.com This work was supported by the author's own resources. No competing interests have been declared.

This is an Open Access article distributed under the terms of the Creative Commons Attribution 3.0 PL License (creativecommons.org/licenses/by/3.0/pl/), which permits redistribution, commercial and non-commercial, provided that the article is properly cited. (C) The Author(s) 2016.

Publisher: Institute of Slavic Studies, Polish Academy of Sciences [Wydawca: Instytut Slawistyki PAN] 
separatystyczne, co według wielu zwolenników corridy de toros ma swoje odzwierciedlenie w oficjalnym negowaniu tego, co "hiszpańskie" (nie katalońskie). Corrida de toros jest również tradycją praktykowaną we Francji i Portugalii, niemniej zazwyczaj jest kojarzona z Hiszpanią. Interesujące w tym kontekście może być to, że od wielu lat toczy się w Hiszpanii spór o to, by wpisać tauromachię na listę światowego dziedzictw UNESCO, co udało się Francji w roku 2011. Po stronie hiszpańskiej pierwszym krokiem tej procedury było przyjęcie przez parlament uchwały, deklarującej tauromachię jako niematerialne dziedzictwo kulturowe Hiszpanii. Historia walki z corridą de toros trwa niemal od samego początku jej istnienia, angażując autorytety polityczne, religijne, czy związane ze sztuką Wydawać by się mogło, że cała Hiszpania - z wyjątkiem Katalonii - praktykuje corridę de toros z równym entuzjazmem. Okazuje się jednak, że nie jest tak do końca. Najbardziej jaskrawym tego przykładem są Wyspy Kanaryjskie, które jako region autonomiczny w roku 1991 przegłosowały uchwałe dotyczącą ochrony zwierząt. W ramach tej decyzji, w artykule 5.1, uwzględniono także corridę de toros, której zakazanie było tylko formalnością z uwagi na fakt, że na wyspach praktycznie nie było śladów zainteresowania tą tradycją. Z kolei w Galicji kwestia stosunku do corridy de toros przybrała nieco odmienny charakter. Region ten nie podnosit - przynajmniej oficjalnie i jednoznacznie - postulatów o delegalizację tauromachii, ale od lat podkreślano, że tradycja organizowania corridy de toros nie nawiązuje do korzeni kulturowych Galicji. W przypadku Katalonii corrida de toros stała się narzędziem do zademonstrowania światu swojej inności od reszty Hiszpanii, a dla nacjonalistycznie nastawionej części Katalończyków stała się dowodem na kulturową wyższość względem sąsiada.

Stowa kluczowe: korrida Katalonia; nacjonalizm; tradycja; kultura; separatyzm; Hiszpania

\section{ZLA TRADYCJA. DELEGALIZACJA CORRIDY DE TOROS W KATALONII}

$\mathrm{D}$ nia 28 lipca 2010 roku w Autonomicznym Parlamencie Katalonii przegłosowano uchwałę delegalizującą corridę de toros w tejże prowincji. Uchwała numer 28/2010 de 3 de agosto została opublikowana 24 sierpnia 2010 roku w numerze 205 „Boletín Oficial del Estado” i spowodowała, że w mediach zawrzało. Przeciwnicy tradycji tauromachicznych ${ }^{1}$ świętowali sukces, a jednocześnie nabrali wiatru w żagle i zintensyfikowali działania zmierzające do objęcia takim samym zakazem innych regionów Hiszpanii. Dla zwolenników corridy de toros z Katalonii porażka w regionalnym parlamencie była dotkliwym ciosem, ale też zaktywizowała to środowisko i popchnęła je do walki o anulowanie dopiero co podjętej uchwały.

Spośród licznych opublikowanych w owym czasie artykułów warto zwrócić uwage na kilka, w których podkreślano najważniejsze kwestie. Przede wszystkim, główny nacisk kładziono na fakt wprowadzenia zakazu drogą legislacyjną. Argument ten był szczególnie istotny dla katalońskich przeciwników corridy de toros, którym bardzo zależało na tym, by zmiany przeprowadzić w drodze głosowania, wynik którego jak się okazało nie był dla nikogo zaskoczeniem (Roger, Geli, 2010, s. 41). Ponadto zauważono, że na kilka tygodni przed datą głosowania najbardziej zaangażowani $w$ to przedsięwzięcie politycy nie poja-

\section{-....}

1 Tradycje, praktyki tauromachiczne - to wszelkie wydarzenia, spektakle i przedstawienia z udziałem byków.

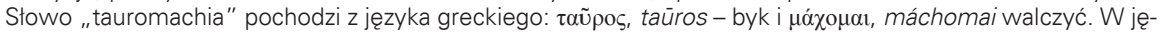
zyku polskim często jest używane określenie „walka byków”, co jest tłumaczeniem angielskiego bullfight. Określenie takie spłyca złożoność tradycji związanych z walką z bykiem, dlatego też w artykule będę używać przyjętego już w literaturze przedmiotu spolszczonego słowa „tauromachia" zamiennie z innym hiszpańskim terminem "corrida de toros", rozumianym jako jedno z najbardziej popularnych widowisk z udziałem byka. 
wiali się w mediach, by nie zaostrzać napięcia, jakie siłą rzeczy istniało pomiędzy zwolennikami i przeciwnikami corridy de toros. W bezpłatnym dzienniku "20 minutos" sytuację tę opisano bardzo dosadnie: „Byki palone, oślepiane, topione czy pobite. Parlament Katalonii zatwierdził w środę zakaz corridy od 2012 roku, ale nadal będzie można organizować uznawane za typowo katalońskie, correbous (...)" (Catalunya prohíbe las corridas de toros, pero seguirá celebrando sus correbous, 2010). Fakt ten interpretowano jednoznacznie jako mający wydźwięk polityczny. Informację o wyniku głosowania łączono również z podkreśleniem, że zakaz organizowania corridy de toros wejdzie w życie dopiero w 2012 roku, co oznacza, że do tego czasu - czyli przez ponad rok - będzie można nadal oglądać te widowiska (Cataluña prohíbe las corridas de toros, 2010). W artykule pojawiła się również informacja o tym, że zwolennicy corridy de toros już zapowiedzieli, że zgłoszą się do Trybunału Konstytucyjnego w celu sprawdzenia konstytucyjności podjętej decyzji. W prasie katalońskiej chwalono ówczesnego premiera José Zapatero, który apelował do sympatyzujących z corridą de toros członków swojej partii PSOE (Partido Socialista Obrero Español o uszanowanie decyzji parlamentu Katalonii. Zwracano przy tym uwagę, że premier nawoływał do tego, by tej decyzji nie upolityczniać, mimo że z pewnością nie wszystkim przypada ona do gustu, a także podkreślat, że prawa Autonomii regionalnych w Hiszpanii są i nadal będą respektowane (Merino, 2010, s. 12).

Decyzja parlamentu Katalonii weszła w życie 1 stycznia 2012 roku, jednak nie oznacza ona definitywnego rozwiązania problemu corridy de toros $w$ tej prowincji. W Hiszpanii, jak w każdym demokratycznym kraju, istnieje wiele instancji w strukturze prawnej, które mogą odwrócić skutki podjętych decyzji. Zwolennicy corridy de toros pierwsze kroki w batalii prawnej skierowali do parlamentu krajowego i za jego pośrednictwem do Trybunału Konstytucyjnego.

W niniejszym artykule spróbuję przedstawić w ogólnym zarysie specyficzną sytuację polityczno-kulturową Katalonii, w której od wielu dziesięcioleci główną determinantą dla podejmowanych działań o charakterze politycznym czy kulturalnym są uwarunkowania historyczne ${ }^{2}$. Jest to szczególnie ważne w kontekście ostatnich wyborów do parlamentu autonomicznego, które odbyły się we wrześniu 2015 roku. Motywem przewodnim kampanii wyborczej były postulaty całkowitego uniezależnienia się prowincji, a ostatecznym skutkiem miało być powołanie do życia nowego państwa na politycznej mapie Europy. Jeśli dokładnie przyjrzymy się wynikom, możemy dojść do wniosku, że najbardziej widoczne konsekwencje ruchów separatystycznych ujawniły się właśnie w tych ostatnich wyborach. Partie proniepodległościowe uzyskały w Katalonii większość w 135-osobowym parlamencie. Zdecydowanie największy sukces odniosła partia Razem na Tak (Junts pel si) - 62 mandaty oraz jej partia sojusznicza Kandydatura Jedności Ludowej (Candidatura d'Unitat Popular) - 10 mandatów. Przedstawiciele obu partii zarówno w kampanii wyborczej jak i po ogłoszeniu wyników wyraźnie opowiadali się za jak najszybszym rozpoczęciem procedury odłączenia się Katalonii od Hiszpanii. Znane już od XVII w. tendencje nacjonalistyczne mają obecnie nową odsłonę. W czasach panowania Filipa IV (XVII W.), który wyraźnie faworyzował Kastylię, w Katalonii doszło do otwartych buntów przeciwko jego decyzjom politycznym (Antczak, 2008, s. 31). Ruchy i dążenia separatystyczne nasiliły się w XIX wieku i niebawem doszło do powstania ugrupowania Lliga Regionalista de Catalunya (Liga Regionalistyczna Katalonii), której głównym celem było dążenie do politycznego i kulturowego uniezależnienia się od Kastylii (Antczak, 2008, s. 42).

\footnotetext{
2 Uważam, że czynniki historyczne, które oddziaływały na kształtowanie się identyfikacji etnicznej i kulturowej Katalończyków, mają tu decydujące znaczenie.
} 
Czy w tym kontekście kwestię corridy de toros można w bezpośredni sposób wiązać z działaniami politycznymi zwolenników bądź przeciwników niepodległości Katalonii? Oczywiście tak. Corrida de toros stała się ważnym instrumentem walki politycznej, albowiem linia podziału pomiędzy zwolennikami a przeciwnikami corridy pokrywa się z grubsza z politycznymi preferencjami mieszkańców Katalonii. Problem ten zostanie przeze mnie szczegółowo opisany w dalszej części artykułu.

\section{CORRIDA DE TOROS W EUROPIE}

Wprawdzie corrida de toros powszechnie kojarzy się z Hiszpanią, to warto pamiętać, że są w Europie także inne kraje, w których tradycje tauromachiczne są praktykowa$n e^{3}$. Samo włączanie tauromachii do kategorii kulturowej, jaką jest tradycja, budzi wiele kontrowersji i wywołuje równie burzliwe dyskusje, jak uznawanie jej przez niektórych za sztukę. Zgodnie z koncepcją Norberta Eliasa, zmiany kulturowe są cechą naturalną społeczności ludzkich i zachodzą wówczas, gdy dochodzi do przesuwania się granicy tolerancji dla określonych zachowań społecznych oraz określonych zwyczajów. W równym stopniu dotyczy to zachowań jednostek jak i stosunku do tradycji. Wprawdzie Elias nie odnosił się bezpośrednio do tauromachii, jednak ukazany przez niego mechanizm zmian jest tu, moim zdaniem, ewidentny. Niewątpliwie praktykowanie corridy de toros, uznawane za tradycję, dotyczy występowania głównych kryteriów definicyjnych tego pojęcia. Jedna z definicji tradycji brzmi: „(...) są to dobra kulturowe przekazywane w czasie (również w przestrzeni), przejmowane i wartościowane" (Jasiewicz, 1987, s. 353). Z kolei o niemal nierozerwalnych więziach człowieka i tradycji pisał José Ortega y Gasset: „Nie rozumie się, że znaczy to po prostu, iż ludzkość to nie rodzaj, ale pewna tradycja, że być człowiekiem jest czymś innym, niż być kamieniem, rośliną, zwierzęciem i Bogiem, gdyż znaczy być w tradycji. Oczywiście, jest tu obojętne, czy ktoś uważa się za tradycjonalistę, czy rewolucjonistę. I jeden, i drugi, chcąc nie chcąc, należą do tradycji (...) Istotą życia ludzkiego jest zatem to, że każda forma wywodzi się z innej i w tym sensie jednostka tkwi w tradycji, a poza nią jest niczym" (Ortega y Gasset, 1993, s. 195-196). Aspekty te są szeroko rozpowszechnione $w$ debacie definicyjnej tauromachii, bowiem nie ulega wątpliwości, że corrida de toros była i jest przekazywana w czasie w procesie enkulturacji i socjalizacji, których główną funkcją jest spajanie kolejnych pokoleń; ponadto jest przekazywana w przestrzeni poprzez implementację na innych obszarach (Ameryka Łacińska); jest również - przynajmniej przez część społeczeństwa pozytywnie wartościowana. Fakt niejednoznacznego stosunku do tradycji wywołuje szereg kontrowersji. W tym sensie można interpretować corridę de toros jako tradycję kontrowersyjną, a co za tym idzie również zagrożoną. Kolejne pokolenia wkraczające na arenę życia społeczno-kulturowego, które zaczynają po swojemu kształtować - kontestują niektóre rozwiązania wypracowane przez pokolenia poprzednie. Tradycje nie są z tego procesu wyłączone, bowiem niektóre z nich, szczególnie te wykraczające swoimi schematami poza tu i teraz przyjęte normy i wzorce zachowań, muszą się zdezaktualizować. Najczęściej mechanizm ten przebiega w sposób „naturalny”, to znaczy obywa się bez ustaleń o charakterze legislacyjnym - po

\footnotetext{
3 Od wieku XIV nie praktykuje się corridy we Włoszech. Wiązało się to w głównej mierze z tym, że było to widowisko zarezerwowane wyłącznie dla szlachty. Rodziny młodych arystokratów, którzy ginęli w czasie walki z bykiem, podejmowały działania na rzecz zakazu organizowania tego typu przedstawień. Włączono w te przedsięwzięcia również stronę kościelną.
} 
prostu tradycja jest zarzucana, przestaje interesować ludzi, nie ma komu jej przekazać lub nie ma kto tego zrobić. Inaczej jest w przypadku zjawisk kulturowych wciąż żywych, którym jednak nie sprzyjają okoliczności, np. ewolucja społeczna skierowana ku odmiennym niż dotychczas wartościom.

Eliasowskie pojęcie zmiany cywilizacyjnej można również interpretować jako kontrolowane przez ramy społeczno-kulturowe sposoby zaspokajania potrzeb jednostek. Każda społeczność wypracowuje te sposoby, tworząc z nich mniej lub bardziej obszerny wachlarz możliwości, które jednostka do niej należąca ma do dyspozycji. Opcje te mają charakter elastyczny, wobec czego ulegają zmianom w czasie (różnice pokoleniowe), jak i w przestrzeni (migracje do odmiennych kulturowo środowisk). Corrida de toros, będąc w minionych wiekach jedną z nielicznych rozrywek dostępnych powszechnie, w czasach współczesnych przegrywa na tym gruncie z licznymi i bardzo zróżnicowanymi rozrywkami. Nawet ci, którzy odczuwają potrzebę ekscytacji widokiem niebezpiecznych czy mrożących krew w żyłach sytuacji, mają dziś do dyspozycji szereg rozwiązań takich, jak telewizja, gry komputerowe, rekonstrukcje historyczne itp. -- wszystko to nie było dostępne ludziom w czasach świetności tauromachii.

Oprócz Hiszpanii, corride de toros organizuje się we Francji oraz w Portugalii. W przypadku francuskim najbardziej popularne są widowiska zwane corrida camarguesa ${ }^{5}$ (w regionie Camarga) oraz corrida landesa ${ }^{6}$ (region południowo-zachodni). Oprócz tego znaczną sławą wśród turystów cieszą się tradycyjne corridy de toros w Arlés, odbywające się zarówno w okresie Wielkiego Tygodnia oraz tzw. Feria de Dax - widowiska tauromachiczne organizowane około 15 sierpnia. Z geograficznego punktu widzenia najbardziej „tauromachiczne" jest południe Francji: Akwitania, Langwedocja-Roussillon, środkowe Pireneje oraz Prowansja-Alpy-Lazurowe Wybrzeże. Mimo iż reszta Francji nie praktykuje tauromachii, nie było to przeszkodą w podjęciu przez środowiska francuskich pasjonatów corridy de toros działań zmierzających do wpisania tej tradycji na listę światowego dziedzictwa kulturowego UNESCO. Kroki podjęte przez Francje przyniosły pozytywny rezultat na początku 2011 roku. Aby zapewnić bezpieczeństwo prawne corridy w Hiszpanii, także miejscowi zwolennicy corridy planują podążyć drogą przetartą przez francuskich sąsiadów. W czasie wywiadów ${ }^{7}$, które prowadziłam wiosną i latem 2012 i 2013 roku, wielokrotnie spotykałam się z argumentami, że przypadek Francji pokazuje, że tauromachia może być traktowana na równi z innymi tradycjami. Pozytywna ocena UNESCO w przypadku Francji, zdaniem aficionados ${ }^{8}$, musi znaleźć swoją kontynuację w Hiszpanii. Obecnie podejmowane są na szeroką skalę działania zmierzające do sfinalizowania tego procesu. Jednym z nich było podjęcie w październiku 2013 roku przez parlament hiszpański (Kortezy) uchwały deklarującej uznanie corridy de toros za niematerialne dziedzictwo kulturowe Hiszpanii.

Corrida de toros jest również tradycją praktykowaną w Portugalii. Podobnie, jak w innych częściach Półwyspu Iberyjskiego widowiska tego typu towarzyszyły wielkim wydarzeniom historycznym, takim jak koronacje czy śluby na dworach królewskich. Uważa się, że początki tych tradycji sięgają wieku XIII. W kolejnych stuleciach corrida de toros w różnych odmianach przeżywała swój złoty wiek, jednak już od 2. połowy XVI wieku zaczęła znacząco różnić się od corridy hiszpańskiej. Przede wszystkim bardzo poważnie potrak-

\section{......}

Corrida de toros została zaimplementowana we Francji w XIX wieku.

Ten rodzaj corridy polega gtównie na uciekaniu przed bykiem na arenie. Toreadorów może być kilku jednocześnie, nie noszą oni popularnych kolorowych strojów (traje de luces) i nie zabijają byka.

6 Widowisko oparte w głównej mierze na spektakularnych skokach przez byka.

7 Wywiady indywidualne pogłębione były częścią badań terenowych, które realizowałam od 2012 do 2013 roku w Hiszpanii, w ramach prac nad rozprawą habilitacyjną dotyczącą dyskursu wokół corridy de toros.

8 Zwolennik, pasjonat, kibic - tu: miłośnik corridy de toros. 
towano bullę De Salute Gregis papieża Piusa V: w roku 1567 zagrozit on ekskomuniką tym, którzy biorą udział w krwawym widowisku (del Moral, 2011, s. 225). Skutkiem tych działań było ostateczne wprowadzenie zakazu zabijania byków na oczach publiczności, co upowszechniło się w wieku XVIII. Najbardziej popularne współczesne widowisko portugalskie nosi miano Forcados i różni się zdecydowanie od corridy de toros w Hiszpanii. Bierze w nim udział grupa ośmiu ludzi, których zadaniem jest sprowokowanie byka do ataku, chwycenie go za rogi i przytrzymanie na miejscu. Zadanie to wykonuje pierwszy w rzędzie, a po wykonaniu chwytu, reszta towarzyszy spieszy z pomocą, by byka przytrzymać. W odróżnieniu od corridy hiszpańskiej, byk nie jest tu zabijany, chociaż zanim dojdzie do jego unieruchomienia, we wczesnej fazie widowiska, wbija mu się w kark banderille, czyli kikudziesięciocentymetrowe włócznie ${ }^{9}$. Po zakończeniu przedstawienia banderille są usuwane, a byk po zaleczeniu ran może być ponownie wykorzystany w widowisku.

\section{PROCES DELEGALIZACJI CORRIDY DE TOROS W UJĘCIU HISTORYCZNYM}

Corrida de toros od samego początku swojego istnienia budziła kontrowersje, podobnie jak wszystkie tego rodzaju zjawiska masowe, począwszy od walk gladiatorów w starożytnym Rzymie. Protesty wobec przemocy w przestrzeni publicznej nie miały oczywiście formy zorganizowanego ruchu, były co najwyżej wyrazem sprzeciwu bardziej wrażliwych jednostek. Z tego też powodu nie mogły zmienić utrwalonych przez stulecia praktyk. Pierwsze symptomy masowej niechęci wobec corridy pojawity się pomiędzy XIV a XVI wiekiem. Być może było to wynikiem wprowadzonego w XIV wieku zakazu organizowania corridy we Włoszech. Sprzeciw wobec praktyk tauromachiznych zyskał silne wsparcie w 1567 roku za sprawą papieża Piusa V, który, jak już wspomniałam wcześniej, wydał bullę De Salute Gregis, potępiającą wszelkie walki ze zwierzętami. Zakaz w przypadku Hiszpanii dotyczył głównie warstwy szlacheckiej, bowiem to z niej rekrutowali się w większości przypadków walczący z bykami, ale także ich pomocników, którzy pochodzili z niższych warstw społecznych. Pius V zdecydował, że ci, którzy zginą w czasie takiej walki nie otrzymają chrześcijańskiego pochówku. Ówcześnie panujący król Hiszpanii, Filip II (15271598), nie uznał nakazów bulli papieskiej i dość szybko udało mu się przekonać następcę Piusa V - papieża Grzegorza XIII, że w rzeczywistości corrida de toros to bardzo pożyteczna dla królestwa tradycja. W efekcie papież ogłosit w 1575 roku bullę Nuper Siquidem, która całkowicie znosiła zalecenia Piusa V. W XVIII wieku za panowania króla Filipa V, corrida de toros spotkała się z niechęcią władz królewskich. Król, który pochodził z Francji, uważał tauromachię za okrutne i krwawe widowisko, co przyniosło w efekcie zakaz udziału w niej arystokracji. Konsekwencją stanowiska króla Filipa $\bigvee$ była zmiana charakteru widowisk tauromachicznych. Do tego czasu podstawową formą corridy była corrida konna, w której główną rolę odgrywali torreadorzy na koniach, wywodzący się w głównej mierze ze szlachty i arystokracji. Decyzja Filipa wynikała z jego niechęci wobec narażania na niebezpieczeństwo zarówno szlachetnie urodzonych jak i koni. W konsekwencji pierwsze skrzypce w przedstawieniach zaczęli odgrywać dotychczasowi pomocnicy toreadorów,

\section{......}

9 Banderilla jest podstawowym narzędziem w hiszpańskiej corridzie de toros w drugiej części widowiska, zwanej tercją de banderillas. Włócznie są ozdabiane kolorowymi wstążkami, dzięki czemu są bardzo dobrze widoczne z każdego miejsca widowni, poza tym intensywne kolory kontrastują zazwyczaj z czarnym umaszczeniem byków. W kark byka powinno być wbitych kilka banderill, a ich haczykowate zakończenie sprawia, że utrzymują się one w ciele byka nawet wtedy, gdy byk biega. 
którzy walczyli pieszo. Szlachta, która wciąż wolała dosiadać konia w czasie walki, chcąc zachować prawo do udziału w widowiskach musiała zwiększyć dystans między koniem a bykiem, zaczęła więc stosować długie piki. W ten sposób narodziła się funkcja pikado$\mathrm{ra}^{10}$. W późniejszych latach podejmowano z różnym skutkiem próby całkowitego zakazu organizowania corridy de toros.

Nowy rozdział w historii corridy de toros nastąpił w okresie dyktatury generała Franco. W tym czasie corrida została uznana za fiesta nacional, czyli święto narodowe. Została także włączona do ogłoszonego 1945 roku Prawa Hiszpanów, czyli zespołu norm, praw i przywilejów przysługujących wszystkim obywatelom, pod warunkiem, że swobody te nie godzą w integralność kraju. W ten sposób corrida została instrumentalnie wykorzystana jako narzędzie integracji oraz stała się elementem gry politycznej, czego skutki możemy obserwować dzisiaj w Katalonii. Dyskusja na temat corridy nabrała dynamiki po roku 1975, po śmierci Franco i zaprowadzeniu demokracji przez Juana Carlosa.

\section{KATALONIA NIE JEST JEDYNA}

Wydawać by się mogło, że cała Hiszpania - z wyjątkiem Katalonii - praktykuje corridę de toros z równym entuzjazmem. Okazuje się jednak, że nie jest tak do końca. Hiszpania jest monarchią konstytucyjną, którą tworzy 17 wspólnot autonomicznych. Taki podział administracyjny gwarantuje kompromis pomiędzy władzą centralną z siedzibą w Madrycie, a społecznościami lokalnymi. Podział ten obowiązuje od 1978 roku i jest efektem przejścia Hiszpanii od centralistycznej dyktatury do pluralistycznej demokracji. Poszczególne regiony Hiszpanii, z których utworzone jest państwo, w różnych okresach historycznych stanowiły odrębne królestwa. Przykładem może tu być chociażby Katalonia, i Aragonia, które jako oddzielne twory państwowe połączyły się w roku 1137, tworząc stosunkowo silne królestwo, liczące się na arenie międzynarodowej. Skutkiem tego było zawarcie w roku 1479 unii personalnej między królem Aragonii - Ferdynandem i królową Kastylii - Izabelą. W ten sposób, pośrednio, Katalonia weszła w związek z Kastylią, co skutkowało wielokrotnie popadaniem w zależność polityczną od tejże i każdorazowo kończyło się podejmowaniem przez Katalończyków walki o niezależność ${ }^{11}$. Sytuacja, w jakiej znalazła się do tej pory bogata i doskonale rozwinięta cywilizacyjnie Katalonia, zmieniła się zdecydowanie wraz z hiszpańskimi podbojami Ameryki i przeniesieniem intensywnego handlu w inne rejony świata. Skutkiem tego zarówno prowincja, jak i sama Barcelona zaczęły tracić na znaczeniu. Nie bez znaczenia na kształtowanie się tożsamości Katalończyków pozostawał także stosunek sąsiedniej Francji, z którą sama Katalonia prawie zawsze utrzymywała poprawne stosunki. W roku 1648 zakończyła się wojna trzydziestoletnia, a wraz z nią doszło do podziału Katalonii pomiędzy Francję i Hiszpanię. Aż do początków XVIII wieku sytuacja w Katalonii daleka była od spokojnej, a ostateczne zakończenie podziałów i włączenie całej Aragonii w skład królestwa hiszpańskiego zakończyło się w drugiej dekadzie XVIII wieku Od razu pojawiła się koncepcja scentralizowanych rządów, w których Kastylia zaczęła odgrywać pierwszoplanową rolę, co w przypadku Katalonii wiązało się między innymi ze zmianą statusu języka katalońskiego - językiem urzędowym został ogłoszony kastylijski (hiszpański). Uważa się,

\footnotetext{
10 Pikador - toreador na koniu, gra gtówną rolę w czasie pierwszej części corridy de toros, zwanej tercją de varas.

11 Najbardziej znane było wystąpienie w roku 1640 mieszkańców Barcelony („wojna żeńców”) i proklamowanie republiki miejskiej. Powstanie zostało stłumione w roku 1652 przez wojska króla Ferdynanda IV.
} 
że w wyniku tych zabiegów kwestie związane z budowaniem i utrwalaniem tożsamości Katalończyków, zaczęły koncentrować się wokół spraw społeczno-kulturowych. Nie mówiono wówczas o dążeniach do uznania Autonomii regionalnej w dzisiejszym rozumieniu. Koniec XIX wieku i początek XX to okres intensywnego rozwoju gospodarczego Katalonii oraz czas odrodzenia tendencji autonomicznych. W roku 1914 katalońscy postowie do Kortezów Generalnych utworzyli Kortezy Katalońskie. W tym samym roku 4 miasta: Barcelona, Girona, Tarraona i Lleida utworzyły związek miast - Mancomunitat Catalunya, który jakkolwiek nie dysponował żadnymi istotnymi prerogatywami, to jednak stanowił symbol rodzących się dążeń autonomicznych. Ostatecznie autonomia katalońska (Generalitat de Catalunya) została zaakceptowana przez parlament hiszpański 17 kwietnia 1931 roku. Apetyt Katalończyków na poszerzanie swojej autonomii zaowocował proklamowaniem niepodległej Republiki Katalońskiej w 1934 roku. Reakcja rządu w Madrycie była natychmiastowa i autonomia Katalonii została tymczasowo zawieszona. W 1936 roku wybuchła w Hiszpanii wojna domowa, w wyniku której władzę objął generał Franco, a sama Katalonia utraciła autonomię na niemal 40 lat. Dopiero śmierć generała Franco w 1975 roku i wejście Hiszpanii na droge demokracji poprzez przyjęcie nowej konstytucji w 1978 roku spowodowało przywrócenie autonomii w ramach Generalitat de Catalunya.

Na mocy ustawy zasadniczej, wspólnoty autonomiczne mają zagwarantowaną swobodę działania w wielu obszarach, między innymi w tych związanych z edukacją ${ }^{12}$ lub gospodarką wewnętrzną. W Rozdziale III konstytucji, poświęconym sprawom wspólnot autonomicznych, w artykułach od 143 do 145 znajdujemy zapisy związane z funkcjonowaniem Autonomii. W artykule 148 wymienione są 22 kompetencje przypisane wspólnotom autonomicznym. Między innymi zawarte są tam przepisy dotyczące kompetencji parlamentów autonomicznych; zarządzania terytorium; urbanistyki i polityki mieszkaniowej; infrastruktury, jeśli jest ona w całości zlokalizowana na terytorium Autonomii; rolnictwa i hodowli - zgodnie z ogólnie przyjętymi zasadami ekonomicznymi obowiązującymi w państwie; eksploatowania lasów i regionów górskich oraz promocji kultury lokalnej oraz edukacji w języku lokalnym.

Kwestia uregulowania prawnego poszczególnych kwestii związanych z funkcjonowaniem Autonomii w Hiszpanii odzwierciedla specyficzną sytuację społeczno-polityczną tego kraju oraz kondycję prawno-społeczną. Wobec interesującego nas zagadnienia, a więc stosunku do corridy de toros - ta regulacja jest niezwykle istotna. Problematyczne okazuje się między innymi interpretowanie zapisów konstytucyjnych w odniesieniu do praktykowania tradycji kulturowych. Zapis w artykule 148 w dość ogólnikowy sposób nawiązuje do kultury lokalnej. O ile nie budzi kontrowersji i wątpliwości określenie „prawo do praktykowania kultury oraz jej promowania", to nie znajdujemy tu przepisu mówiącego jednoznacznie o prawie parlamentów autonomicznych do decydowania o znoszeniu przepisów ogólnych dotyczących kultury, w wyniku wejścia w życie lokalnych, autonomicznych uchwał. Powszechnie uważana za element kultury hiszpańskiej corrida de toros, została tak właśnie zdefiniowana przez obecnego ministra edukacji, kultury i sportu José Ignacio Werta („Wert: 'Los toros son un ingrediente de la marca España'”, 2012). W wyniku tego podniosły się głosy zwolenników tauromachii, którzy uznali za niezgodne z konstytucją zakazanie przez parlament autonomiczny Katalonii organizowania corridy de toros. W konsekwencji, wczesną wiosną 2012 roku zaczęto zbiórkę podpisów pod petycją społeczną do Kortez

\section{-....}

12 Ostatnio dość głośno są komentowane decyzje obecnego ministra kultury José Ignacio Werta, który postuluje uregulowanie na szczeblu centralnym kwestie nauczania w Katalonii i na Balearach języka hiszpańskiego (kastylijskiego); por.: "Wert planea establecer convenios con escuelas privadas que "garanticen" la enseñanza del castellano en Catalunya y Balears" (2012). 
w celu skierowania uchwały autonomicznej do Trybunału Konstytucyjnego. W czasie prowadzonych przeze mnie w marcu 2012 roku badań terenowych rozmawiałam z jednym z autorów owej petycji, Fernando del Arco de lzco, który tłumaczył mi, że „jeśli konstytucja daje prawo wszystkim obywatelom do korzystania z szeroko rozumianej kultury, to lokalne przepisy nie mogą tego prawa znieść, bo w konsekwencji katalońscy aficionados są tego prawa pozbawieni". Ostatecznie zebrano prawie 600 tysięcy podpisów ("590.000 firmas para declarar los toros Bien Cultural en Catalunya", 2012). Jesienią 2012 roku petycja trafiła do parlamentu i w obecnej chwili czekamy na wynik tej obywatelskiej inicjatywy. Równolegle polemika zwolenników corridy de toros kieruje się przeciwko działaniom podejmowanym przez oponentów praktykowania tego rodzaju tradycji.

Oprócz sprzeciwów wobec tauromachii płynących z Katalonii warto zwrócić uwage także na inne regiony Hiszpanii, w których stosunek do corridy de toros niekoniecznie pokrywa się z często stereotypowym postrzeganiem Hiszpanii jako kraju pod tym względem jednorodnego. Najbardziej jaskrawym tego przykładem są Wyspy Kanaryjskie, które jako region autonomiczny w roku 1991 przegłosowały uchwałę dotyczącą ochrony zwierząt. W ramach tej decyzji, w artykule 5.1, uwzględniono także corridę de toros, której zakazanie było tylko formalnością z uwagi na fakt, że na wyspach prawie nie było śladu zainteresowania tą tradycją ${ }^{13}$. Prawdopodobnie wynikało to ze specyficznej sytuacji społeczno-ekonomicznej regionu, który od wielu już lat koncentrował się na przemyśle turystycznym. Goście odwiedzający Wyspy Kanaryjskie w znacznej większości nie byli nastawieni na poznawanie tradycyjnej hiszpańskiej kultury, której częścią jest corrida. Planowali raczej wypoczynek na kanaryjskich plażach i kontemplowanie niezwykłej przyrody. Ten rodzaj turystyki przypieczętował los corridy de toros, której autochtoni także nie chcieli oglądać. Decyzja ta była zatem podyktowana dążeniami lokalnych władz do wykreowania wizerunku mieszkańców wysp, jako tych, którzy idąc z duchem czasu, rezygnują z niepopularnych tradycji. W jaskrawej sprzeczności z taką argumentacją stoją jednak zapisy w artykule 5.2, które pozwalają na praktykowanie walk kogutów w tych miejscowościach, w których stanowią one odwieczną tradycję.

Z kolei w Galicji kwestia stosunku do corridy de toros przybrała nieco odmienny charakter. Region ten nie podnosił - przynajmniej oficjalnie i jednoznacznie - postulatów o delegalizację tauromachii, ale od lat podkreślano, że tradycja organizowania corridy de toros nie nawiązuje do korzeni kulturowych Galicji. W związku z tym, aby zademonstrować swoje stanowisko w tym temacie pod koniec roku 2011 w Parlamencie Autonomicznym Galicji przegłosowano zakaz wstępu na plaza de toros dzieciom młodszym niż 12 lat (Salgado, 2011). Decyzję tę tłumaczono między innymi tym, że corrida de toros jako specyficzny rytuat, związany z przemocą, może pozostawiać w psychice dzieci nieodwracalne zmiany. Argumentowano także, iż epatowanie przemocą w przestrzeni publicznej może przyczynić się do zobojętnienia młodych ludzi na kwestie przemocy wobec zwierząt i w rezultacie doprowadzić do wytworzenia postaw patologicznych. Ten rodzaj argumentacji, jakkolwiek brzmiący sensownie z punktu widzenia wrażliwości zachodnioeuropejskiej, dla której ochrona dzieci jest szczególnie istotna, nie znajduje jednakże potwierdzenia w żadnych opracowaniach naukowych, na co chętnie powołują się zwolennicy tauromachii. Niemal każde z działań podejmowanych przeciwko tauromachii ma na celu wprowadzenie całkowitej lub przynajmniej częściowej rezygnacji z organizowania widowisk tego rodzaju. Moim zdaniem mamy tu do czynienia z procesem zmian tradycji rozumianej jako zjawisko społeczno-kulturowe. Wspomniany proces zmian był przed-

- •.・

13 Podobnie jak organizowanie walk psów. Por. Fernández (2010) (8 stycznia 2015).. 
miotem zainteresowania Norberta Eliasa, który twierdził, że życie społeczne poprzez swój naturalny charakter podlega mechanizmom procesualnym. Za optymalną metodę umożliwiającą ukazanie tego procesu, uznawał Elias dążenie do syntezy w tworzeniu wieloczynnikowych "modeli struktur i procesów czasoprzestrzennych" (Elias, 2003, s. 23). Można zatem wobec powyższego przyjąć założenie, że obecność tauromachii w społeczeństwie oraz implikowany tym stosunek do tego rodzaju praktyk, jest w gruncie rzeczy takim procesem. Rozpatrywanie tego zjawiska zarówno z punktu widzenia przeciwników, jak i zwolenników tauromachii - wyraźnie daje wyraz koncepcji "odwiecznej obecności” corridy de toros w społeczeństwie hiszpańskim. Różnicę stanowi jedynie stosunek do tej "odwiecznej obecności". Zdaniem zwolenników uprawomocnieniem ich argumentacji za zachowaniem status quo jest właśnie owa „odwieczna tradycja”, a współczesna kondycja tradycji wymaga odgórnego wprowadzenia ram ochronnych dla jej praktykowania. Zmiana ma mieć zatem charakter legislacyjny. Z kolei przeciwnicy corridy de toros ów legislacyjny charakter zmiany w relacji społeczeństwo - tauromachia upatrują w osiągnięciu celu, jakim jest jej delegalizacja.

\section{PROCES DELEGALIZACJI CORRIDY DE TOROS W KATALONII}

Początki „walki” Katalonii z tauromachią można dość dokładnie prześledzić. Nie zawsze jednak specyficzna postawa Katalonii odnosiła się bezpośrednio do corridy de toros. U podstaw tej szczególnej sytuacji leży fakt, że "Katalończycy (...) czują się różni od Hiszpanów i swą odmienność chętnie podkreślają" (Obtułowicz, 2007, s. 37). Jest to bez wątpienia rezultat decyzji historycznych, które miały miejsce w okresie średniowiecznym oraz w czasach późniejszych, które doprowadziły do unii Katalonii z koroną hiszpańską w XV wieku. Przez kolejne wieki Katalończycy podkreślali swą odrębność głównie poprzez dążenie do odrodzenia narodowego tego regionu, co szczególnie przybrało na sile w wieku XIX. W tym też okresie dochodzą do głosu postulaty, których myśl przewodnia koncentrowała się na podniesieniu statusu języka katalońskiego do rangi języka narodowego (w Katalonii). Współcześnie efektem wymiernym w tym zakresie jest to, że możemy mówić o procesie katalonizacji, który obejmuje nie tylko kwestie związane z językiem, ale także z polityką, ekonomią oraz szeroko rozumianą kulturą. Język kataloński jest obecny w Katalonii na każdym kroku: w środkach komunikacji, w szkołach, urzędach, na placach zabaw, w kinach i restauracjach. „Obecnie wydawane są cztery dzienniki po katalońsku i ponad dwieście rozmaitych periodyków. Katalończycy mają własną stację radiową i kilka kanałów telewizyjnych. Rośnie także liczba książek publikowanych po katalońsku" (Obtułowicz, 2007, s. 37). Odróżnianie się od reszty Hiszpanii w przypadku Katalonii nie ogranicza się jedynie do kwestii językowych i postulatów kojarzonych powszechnie z polityką oraz ekonomią ${ }^{14}$. Ogromne znaczenie, szczególnie w ostatnich latach, ma także aspekt kulturowy. Katalończycy podkreślają, że nie stanowią jednego narodu z innymi nacjami kraju, a co za tym idzie, nie mogą podzielać wszystkich praktyk kulturowych charakterystycznych dla Hiszpanii. Oczywiście najwięcej zastrzeżeń dotyczy corridy de toros, która w pewnym sensie stała się niechcianym w Katalonii symbolem supremacji

\section{-.....}

14 Do dziś podkreśla się szczególne cechy Katalonii w aspekcie ekonomicznym w odniesieniu do historii i współczesności: niezależne kontakty handlowe z Europą i Azją, pierwsze ubezpieczenia morskie, pierwszy zegar na wieży (i inne) (Obtułowicz, 2007, s. 26). 
Madrytu. W dużej mierze wynika to z faktu, że Katalonia jest w pełni świadoma swojej uprzywilejowanej (w pewnym sensie) sytuacji w Europie. Szczególną rolę w tej pozytywnej odrębności odgrywa oczywiście stolica Katalonii - Barcelona. Jest to miasto, które nie tylko rozwija się ekonomicznie w imponującym tempie i przyciąga inwestorów z całego świata, ale równocześnie cieszy się ogromną popularnością wśród turystów. Nie może więc dziwić fakt, że władze autonomiczne, chcąc zachować wizerunek nowoczesnego społeczeństwa, zaczęły dążyć do rozdzielenia kontrowersyjnych tradycji hiszpańskich od regionu katalońskiego. Jak wyglądała ta droga?

Jak wspomniałam na początku artykułu, zakaz organizowania corridy de toros został wprowadzony w Katalonii latem 2010 roku i wszedł w życie z początkiem roku 2012. Sam pomysł był wynikiem działań ILP (Iniciativa Legislativa Popular), czyli "obywatelskiej inicjatywy ustawodawczej", która w państwach demokratycznych umożliwia wystąpienie z pomysłami legislacyjnymi odpowiednio licznej grupie obywateli ${ }^{15}$. W przypadku Katalonii mamy bardzo wyraźny kontekst legislacyjny związany z tymi założeniami. Dotyczy to między innymi uchwały parlamentu katalońskiego o numerze 3/1988 de 4 de marzo, która reguluje prawną ochronę zwierząt, a także zakazuje budowania nowych plaz de to$\operatorname{ros}^{16}$ w całej Katalonii i ogranicza dostęp do udziału w widowiskach osobom młodszym niż 14 lat. Do takiego stanu rzeczy przyczynili się przede wszystkim parlamentarzyści z partii CiU (Convergència i Unió), a same głosy rozłożyły się następująco: 68 za, 55 przeciw i 9 wstrzymujących (Belmonte, 2010). Przewodniczący parlamentu José Montilla, związany z partią PSC (Parido de los Socialistas de Cataluña), głosował przeciwko zakazowi. Ponadto w przypadku socjalistów i nacjonalistów z partii centroprawicowych nie została wprowadzona dyscyplina głosowania, a więc przynajmniej teoretycznie parlamentarzyści mieli możliwość wyrażenia swojej opinii zgodnie z sumieniem. Deputowani z PP (Partido Popular ${ }^{17}$, na znak solidarności z tauromachią założyli czarne koszulki z wizerunkiem białego byka i sercem z napisem CAT (czyli skrótem od Cataluña) (por. "Cataluña vota NO a hacer de las MATANZAS DE TOROS una FIESTA", 2010; "Toros, no. Se acabó la "fiests" en Catalunya", 2010). Ta inicjatywa - w sumie rozdano 135 koszulek dla wszystkich parlamentarzystów - albo, jak chcą niektórzy, prowokacja, nie pomogła w zachowaniu status quo corridy de toros w Katalonii.

Warto przy tej okazji podkreślić, że do tradycji tauromachicznych obok corridy de toros zalicza się również między innymi wspomniane wcześniej correbou ${ }^{18}$ - katalońską zabawę z bykiem na placu miasta Cardona, która nie doczekała się takiej fali krytyki jak corrida. Wręcz przeciwnie, w uchwale czytamy, że zakaz dotyczy takich widowisk, jak „Corrida de toros i widowiska z udziałem byków, które wiążą się z ich śmiercią oraz używaniem takich narzędzi jak piki, banderille i szpady, podobnie jak wszelkie inne spektakle tauro-.....

15 Dla przykładu w Polsce wymagane jest 100000 podpisów. W Hiszpanii mamy dwa poziomy inicjatyw: (1) ogólnokrajowy, w którym wymagane jest 500000 podpisów oraz (2) regionalny, w którym w zależności od liczby mieszkańców jest ściśle określona liczba wymaganych podpisów. Dla Katalonii jest to 50000 (dla porównania w Andaluzji jest to 75000 - najwięcej w Hiszpanii).

16 Wydaje się to o tyle interesujące, że w samej Barcelonie działały w sumie trzy palzas de toros: El Torín (18341946), Las Arenas (1900-1977) i Monumental (1916-2011). Las Arenas w roku 2011 zostało przekształcone po wieloletniej budowie w centrum handlowe, a Monumental od roku 2012 jest zamknięta, działa tam tylko muzeum tauromachii. Dla ścisłości należałoby dodać jeszcze czwartą plaza de toros, zwaną El Sport z 8000 miejsc, która działała w latach 1914-1916 (Felices, 2010, ss. 31-32). Zorganizowano na niej zaledwie 11 corrid de toros i 9 novillad, nie zyskała więc szczególnego znaczenia i raczej miała charakter przejściowy i tymczasowy.

17 Z partii tej wywodzi się premier Hiszpanii Mariano Rajoy.

18 Correbou to tradycja wywodząca się z XIV wieku. Polega na zorganizowaniu placu miasta na sposób areny, na którą wkracza byk i atakuje schowanego w specjalnym koszu wiklinowym, zwanym "cargolera", człowieka, który ukazuje bykowi tylko swoje ręce i nogi. Zgromadzony na widowni ludzie kibicują zarówno śmiałkowi, jak i bykowi. 
machiczne odbywające się poza lub na plaza de toros, z wyjątkiem tych, o których mowa w ustępie 2" (por. Boletin Oficial del Estado, 2010). Rzeczony ustęp 2 dokładnie precyzuje wyjątki: nie są zakazane te widowiska z udziałem byka, w których nie następuje śmierć byka (jak w przypadku correbou) oraz w żaden inny sposób nie jest zadawane bykowi cierpienie. W czasie moich badań terenowych w Hiszpanii w 2012 roku, moi informatorzy - zwolennicy corridy de toros - bardzo często zwracali uwage na tę niekonsekwencję w stosunku do widowisk z udziałem byków: Dlaczego się to odrzuca? Bo jest hiszpańskie. Ale [Katalończycy - przyp. MZ-K] mają swoje tradycje tauromachiczne, correbou. (...) Tak jest. Zakazali jako kontra wobec Hiszpanii, a nie jako wyraz zainteresowania losem byków, absolutnie. Jesteśmy krajem demokratycznym, w którym mamy zagwarantowaną wolność ${ }^{19}$. Motywom humanitarnym, które miały przyświecać zakazowi organizowania corrid de toros w Katalonii moi informatorzy jednoznacznie nadawali wydźwięk polityczny: Przypadek Katalonii to przykład nacjonalizmu katalońskiego, oni chcą się oderwać od Hiszpanii i szukają byle pretekstu. To czysto polityczna decyzja, niezwiązana z humanitaryzmem²0.

Decyzja o zakazie corridy de toros natychmiast po jej wejściu w życie wzbudziła wielkie emocje. Dla aficionados był to cios i w ich opinii zamach na gwarantowane konstytucją wolności i wyrok na istotny element kultury. Dla przeciwników corridy de toros przypadek kataloński jest przykładem właściwie obranego kierunku zmian, w jakim kontrowersyjne tradycje, także te z udziałem zwierząt, powinny zmierzać. Moi informatorzy - przeciwnicy tauromachii - podkreślali w wywiadach, że: Wciąż jeszcze w wielu miejscach Hiszpanii organizuje się widowiska tauromachiczne ze względów finansowych ${ }^{21}$. Dla aficionados wraz z decyzją o zakazie rozpoczął się proces zaskarżania podjętej uchwały pod zarzutem jej niezgodności z ustawą zasadniczą. Wniesienie sprzeciwu wobec podjętej uchwały do Trybunału Konstytucyjnego jeszcze nie doczekało się opinii tejże instytucji. Niemniej jednak, jak widać między innymi na przykładzie dyskusji w prasie, decyzja może mieć nawet wymiar międzynarodowy, choćby z tego względu, że skoro we Francji corrida de toros została uznana za Niematerialne Dziedzictwo Kulturowe UNESCO, to niezwykłe wydawałoby się potępienie tej samej tradycji w sąsiednim kraju („Las corridas de toros serán declaradas Bien de Interés Cultural. La Fiesta Nacional no podrá ser prohibida en ninguna parte de España", 2012).

W przestrzeni publicznej, co szczególnie wyraźnie można zauważyć wśród aficionados, podkreśla się polityczne podłoże decyzji o zakazie praktykowania corridy de toros. W pewnym sensie potwierdzeniem tej tezy są moje prywatne rozmowy, które wiele razy prowadziłam z Katalończykami. Bardzo powszechne są opinie, że Katalończycy nie chcą być kojarzeni z Kastylią, a ponieważ corrida de toros to jej tradycja i symbol, więc Katalończycy go u siebie nie chcą. Komentarze na ten temat są oczywiście bardzo różne. W literaturze tauromachicznej można spotkać choćby takie: „Katalonia może żyć bez Tauromachii i Tauromachia może żyć bez Katalonii, ale jest to albo wydaje się, że jest: sprefabrykowany rozwód z tym, co hiszpańskie, postawa wynikająca z kontrkultury albo z przymusu" (Arranz, 2011, s. 70).

Wątki koncepcji Eliasa są szeroko rozpowszechnione w całym dyskursie dotyczącym corridy de toros. Dotyczy to $w$ większości przypadków działań podejmowanych przez przeciwników tauromachii. To, co kiedyś traktowane było za rzecz świętą, niezmienialną, bo nie podlegającą ocenie i negatywnemu wartościowaniu, obecnie spotyka się z zażartą

\section{-....}

19 Wywiad przeprowadzony w kwietniu 2012 roku.

20 Wywiad przeprowadzony w sierpniu 2012 roku.

21 Wywiad przeprowadzony w maju 2012 roku. 
krytyką. I tak, jak dawniej uchodziło jedzenie współbiesiadników z jednego naczynia - dla obecnego społeczeństwa zachowanie niewyobrażalne, tak tauromachia, praktykowana bez większych przeszkód w dawnych czasach - współcześnie jest katalizatorem dążenia do zmiany zastanej przez kolejne pokolenia rzeczywistości. Oznacza to, że tauromachia nie jest pod tym względem wyjątkową tradycją i podobnie jak inne, obecnie uznane za niewłaściwe i przestarzałe, powinna być, zdaniem antitaurinos zniesiona. Fernando Álvarez - znany hiszpański etolog i przeciwnik tauromachii pyta retorycznie w tym kontekście: "(...) czy mamy ślepo kontynuować praktykowanie wszystkich naszych tradycji?" (Álvarez, 2008).

\section{PODSUMOWANIE}

Dążenie do odrębności w przypadku Katalonii charakteryzuje się co najmniej dwoma odmiennymi postawami: (1) separacja Regionu Autonomicznego i uzyskanie niepodległości; (2) dążenie do uzyskania niezależności w większości aspektów życia polityczno-ekonomicznego, bez konieczności tworzenia niepodległego państwa. Druga postawa wiąże się między innymi z tym, że odrębność Katalonii zawsze była przedstawiana jako „bardziej wyważona" w porównaniu z separatyzmem Basków, którzy w swoich planach zawsze zakładali oderwanie się od Hiszpanii, za pomocą wszelkich dostępnych środków z przemocą włącznie ${ }^{22}$. Katalonia tymczasem nie była jednoznacznie kojarzona z chęcią oderwania się od Hiszpanii i utworzeniem samodzielnego państwa. Wprawdzie takie poglądy pojawiały się również, niemniej jednak, główny postulat dotyczył „(...) stworzenia warunków do swobodnego rozwoju kultury, tradycji, a nade wszystko języka katalońskiego" (Obtułowicz, 2007, s. 26). Corrida de toros stała się zatem narzędziem dla zademonstrowania światu swojej inności od reszty Hiszpanii, a dla nacjonalistycznie nastawionej części Katalończyków stanowi dowód kulturowej wyższości względem sąsiada.

\section{BIBLIOGRAFIA}

90.000 firmas para declarar los toros Bien Cultural en Catalunya. (2012, marzec 22). Pobrano 29 stycznia 2015, z http://www.publico.es/espana/590-000-firmas-declarar-toros. html

Agulla, J. (2011). Parece que fue ayer. W Peña Los Olivares [folder informacyjny Feria Taurina] (ss. 61-63). San Sebastián de los Reyes.

Álvarez, F. (2008, kwiecień 4). Nueve razones para abolir la fiesta nacional. Pobrano 12 czerwca 2015, z http://blogs.publico.es/dominiopublico/424/nueve-razones-para-abolir-la-fiesta-nacional/

Antczak A. (2008). Ksztattowanie się tożsamości narodowej wspólnot autonomicznych w Hiszpanii. Warszawa: Akademia Obrony Narodowej.

\section{$\cdots \cdots$}

22 Bez wątpienia najbardziej charakterystyczną cechą nacjonalizmu baskijskiego jest ETA - Euskadi Ta Askatasuna - Kraj Basków i Wolność. Organizacja powstała w roku 1959, a jej głównym celem była zbrojna walka o niepodległość Kraju Basków. Od lat 60. XX w. w wyniku akcji terrorystycznych organizowanych przez ETA zginęło ponad 800 osób. Pod koniec 2011 roku ETA ogłosiła zakończenie zbrojnej walki oraz bezterminowe zawieszenie broni. Por. „ETA anuncia el fin del terrorismo” (b.d.). 
Arranz, Á. (2011, grudzień). Al toro por los cuernos. Caireles, (30), 67-70.

Belmonte E. (2010, lipiec 28). Cataluña prohíbe los toros. Pobrano 22 stycznia 2015, z http://www.elmundo.es/elmundo/2010/07/25/barcelona/1280081754.html

Boletín Oficial del Estado. (2010, sierpień 24). Nr 205, sekcja I, s. 73974. Pobrano 22 stycznia 2015, z http://www.derechoanimal.info/bbdd/Documentos/791.pdf

Casals, J. (2012). Bravura enfrentada. Aplausos, (1797), 37-39.

Cataluña prohíbe las corridas de toros, (2010, lipiec, 28). Pobrano 21 kwietnia 2016, z http://www.bbc.com/mundo/cultura_sociedad/2010/07/100728_catalunya_toros_lh. shtml

Cataluña vota NO a hacer de las MATANZAS DE TOROS una FIESTA. (2010, lipiec, 28). Pobrano 22 stycznia 2015, z http://www.lasmalaslenguas.es/2010/07/28/catalunya-vota-no-corridas-toros/

Elias. N. (2003), Zaangażowanie i neutralność, Warszawa: PWN.

ETA anuncia el fin del terrorismo. (b.d.). Pobrano 15 stycznia 2015, z http://cadenaser. com/ser/2011/10/20/espana/1319068228_850215.html

Fatjó, J., Amat, M., \& Manteca, X. (2007). Las corridas de toros y la ciencia del bienestar animal. W Altarriba: Cuadernos para dialogar sobre animales: La cuestion de los toros (ss. 60-65). Barcelona: Fundación Altarriba.

Felices, R. (2010). Catalunya Taurina: Una historia de la tauromaquia catalana de la Edad Media a nuestros días. Barcelona: Bellaterra.

Fernández, S. (2010, styczeń 11). Canarias prohibió los toros... aunque no los gallos. Pobrano 8 stycznia 2015, z http://www.lavanguardia.com/ciudadanos/noticias/20100111/ 53866564293/canarias-prohibio-los-toros...-aunque-no-los-gallos-gran-canaria-cabreracoalicion-canaria-partido-p.html

Jasiewicz, Z. (1987). Tradycja. W Z. Staszczak (Red.), Stownik etnologiczny: Terminy ogólne (s. 353). Warszawa: PWN.

Las corridas de toros serán declaradas Bien de Interés Cultural. La Fiesta Nacional no podrá ser prohibida en ninguna parte de España. (2012, wrzesień 26). Pobrano 22 stycznia 2015, z http://www.elconfidencialdigital.com/politica/Interes-Cultural-Fiesta-Nacional-Espana_0_1914408541.html

Merino J.C. "Respetaré las competencias": gesto del presidente con Catalunya por los toros, „La Vanguardia”, 31 lipca 2010, s. 12.

Moral, J. A. del. (2011). Cómo ver una corrida de toros: Manual de tauromaquia para nuevos aficionados. Madrid: Allianza.

Obtułowicz, B. (2007). „Katalończycy nie są tacy sami jak pozostali Hiszpanie”: Kształtowanie się poczucia odrębności Katalończyków w XVIII i XIX w. W A. Sawicka (Red.), Almanach kataloński (Katalonia-Walencja-Baleary-Andorra) (ss. 17-37). Kraków: Księgarnia Akademicka. (Studia Iberystyczne, 6)

Ortega y Gasset J. (1993) Velázquez i Goya, Warszawa: Czytelnik.

Pedraza Jiménez, F. B. (2008). Iniciación a la fiesta de los toros. Madrid: EDAF.

Roger Maiol, Geli Carles (2010), Cataluña entra a matar, „El País”, 28 lipca 2010, s. 41.

Salgado M. (2010, lipiec 28), Catalunya prohíbe las corridas de toros, pero seguirá celebrando sus correbous. Pobrano 21 kwietnia 2016, z http://www.20minutos.es/noticia/777158/0/catalunya/toros/correbous/

Salgado, X. (2011, grudzień 23). Galicia prohibirá el acceso de menores de 12 años a espectáculos taurinos. Pobrano 8 stycznia 2015, z http://www.elmundo.es/elmundo/2011/12/23/galicia/1324647783.html 
Sawicka A. (2006), Drogi i rozdroża kultury katalońskiej. Kraków: Księgarnia Akademicka Toros, no. Se acabó la "fiests” en Catalunya. (2010, sierpień 1). Pobrano 22 stycznia 2015, z http://smfdiario.blogspot.com/2010/08/toros-no-se-acabo-la-fiesta-en.html

Wert planea establecer convenios con escuelas privadas que "garanticen" la enseñanza del castellano en Catalunya y Balears. (2012, październik 3). Pobrano 18 grudnia 2014, z http://www.publico.es/espana/443359/wert-planea-establecer-convenios-con-escuelas-privadas-que-garanticen-la-ensenanza-del-castellano-en-catalunya-y-balears

Wert: "Los toros son un ingrediente de la marca España”. (2012, luty 28). Pobrano 1 stycznia 2015, z http://www.publico.es/espana/wert-toros-son-ingrediente-marca.html 